\title{
Kinetic Studies of HRP Adsorption on ds-DNA Immobilized on Gold Electrode Surface by EIS and SPR
}

\author{
Danielle C. M. Ferreira, * Renata K. Mendes and Lauro T. Kubota \\ Instituto de Química, Universidade Estadual de Campinas, Unicamp, CP 6154, \\ 13083-970 Campinas, SP, Brazil
}

\begin{abstract}
Este trabalho descreve a construção de um filme de multicomponentes via método layer-bylayer (LbL) e a análise cinética da interação da enzima peroxidase de raiz forte (HRP) sobre a camada de ds-DNA de timo de bezerro formada numa superfície de ouro modificada. As técnicas de ressonância de plásmon de superfície (SPR) e a espectroscopia de impedância eletroquímica (EIE) foram usadas para caracterizar a construção do filme sobre a superfície de ouro. A ressonância de plásmon de superfície forneceu informações essenciais para o estudo e caracterização da interação proteína e ácido nucléico. Este método não necessita de marcador e monitora as interações em tempo real. Os estudos cinéticos obtidos por SPR da formação do filme de HRP sobre o ds-DNA apresentaram valores de $24,7 \mathrm{~L} \mathrm{~mol}^{-1} \mathrm{~s}^{-1}$ e $1,2 \times 10^{-3} \mathrm{~s}^{-1}$ para $\mathrm{k}_{\mathrm{a}}$ e $\mathrm{k}_{\mathrm{d}}$, respectivamente. A energia livre de Gibbs obtida para o sistema foi de $-23,1 \mathrm{~kJ} \mathrm{~mol}^{-1}$. Os resultados obtidos mostram que a interação das moléculas da enzima sobre o ds-DNA é cinética e termodinamicamente favoráveis e a interação entre as camadas ocorre principalmente pela atração de cargas opostas.
\end{abstract}

This paper describes the construction of a multicomponent film via layer-by-layer (LbL) method and the kinetic analysis of the interaction between horseradish peroxidase (HRP) enzyme on calf thymus double-stranded DNA layer on a modified gold surface. Surface plasmon resonance (SPR) and electrochemical impedance spectroscopy (EIS) are used to characterize the successful construction of the film on the gold surface. Surface plasmon resonance provided essential information for the study and characterization of protein and nucleic acid interaction and this method is label-free and monitors the interactions in real time. The kinetic studies determined by SPR of the horseradish peroxidase film formation on ds-DNA layer showed values of $24.7 \mathrm{~L} \mathrm{~mol}^{-1} \mathrm{~s}^{-1}$ and $1.2 \times 10^{-3} \mathrm{~s}^{-1}$ for $\mathrm{k}_{\mathrm{a}}$ and $\mathrm{k}_{\mathrm{d}}$, respectively. The Gibbs free energy obtained for the system was $-23.1 \mathrm{~kJ} \mathrm{~mol}^{-1}$. The results obtained show that the interaction of the enzymes molecules on ds-DNA is kinetically and thermodynamically favourable and the interaction among the layers probably occurs mainly by attraction of opposite charges.

Keywords: SPR, EIS, kinetic adsorption, DNA, HRP, protein-DNA interaction

\section{Introduction}

The interaction of nucleic acids with protein has been a primary area of interest for therapeutic development and in the study of cellular processes. ${ }^{1-3}$ Development of devices based on this interaction presents application in the investigations of the toxicity pathways of nucleic acid. Recently, electrochemical sensors have been developed for the rapid detection of DNA damage. ${ }^{4-7}$ Such devices are being successfully used in food industry, environmental fields and clinical chemistry. Biosensors for such analysis can be prepared with multicomponent films of polyions

*e-mail: daniellecristhina@hotmail.com and other charged materials and to achieve high specificity, high sensitivity, rapid response and flexibility of use, it is clear that the research continues to focus on new assembly strategies. In this sense, layer-by-layer assembly is a comparatively new method by which thin films particularly of oppositely charged layers are deposited. There are many advantages of layer-by-layer assembly technique and these include simplicity, universality and thickness control in nanoscale. Layer-by-layer assembly process does not require highly pure components and sophisticated hardware and its properties can be controlled by choosing molecules and number of layers. ${ }^{8-10}$ Although most of these LbL films have been used in amperometric enzyme biosensor construction, some groups have reported sensors 
with multilayers formed on quartz crystal microbalance, ${ }^{8,11}$ surface plasmon resonance ${ }^{12,13}$ or electrochemical ${ }^{14,15}$ detection techniques.

Construction of multilayer films usually relies on the electrostatic attraction between positively and negatively charged materials, although other interactions can be exploited thus as including hydrogen bonding, charge transfer interactions and stereo-complex formation. ${ }^{16,17}$ Therefore, the materials choice and optimization of experimental variables such as ionic strength and $\mathrm{pH}$ are important factors for the construction of these layers. The LbL technique has been found as a highly useful way for assembling a number of organic and inorganic compounds, including proteins, DNA, dendrimers and nanoparticles. The organized multilayer architectures have attracted great interest because of their broad range of applications in the fields of biosensors, nonlinear optical devices and surface modification. ${ }^{12,13,18-21}$

Interest in dendrimers has grown in the last decade due to the use of these molecules in numerous industrial and biomedical applications. Dendrimers are different from traditional polymers; they have a multi-branched, three dimensional architecture with very low polydispersion ability and high functionality. A great number of dendrimer structures have been developed and investigated based on inspiration in the biological systems, among them polyamidoamine (PAMAM) polymers. Particular interest is devoted to the fourth generation one due to its spherical structure and good biocompatibility, which can provide a flexible space created within the voids of dendritic building blocks, which can possibly encapsulate various small guest molecules. ${ }^{23,24}$ In previous works, the formation of PAMAM and PAMAM/ds-DNA layer on gold surface was investigated. ${ }^{25-27}$

Biological compounds including DNA, RNA, enzymes and proteins can be regarded as natural charged functional polymers. They are also widely used in the layer-by-layer multilayer formation. ${ }^{8,28,29}$ Therefore, characterization of DNA-protein interactions is of great importance in the study of biological processes, mainly in biosensors, employing DNA-enzyme layer-by-layer films. These devices show great potential in predicting genotoxicity of drugs and environmental chemicals, thus future tools in chemical product development studies are very important. ${ }^{18}$ Schubert et al. ${ }^{3}$ reported kinetic and thermodynamic characterizations of the ss-DNA and replication protein A using SPR and fluorescence correlation spectroscopy. However, no studies about the kinetics adsorption of horseradish peroxidase and ds-DNA were reported.

Surface plasmon resonance is a method that can be used to monitor the interactions between biomolecules. ${ }^{30-32}$
Continuous monitoring of the SPR signal allows studying the kinetics of binding in real time. The main advantage of SPR is that no particular property of the interacting molecules is required; being possible to determine the true association and dissociation rates of the complex formation. . $^{1-3,33}$

Thus, in the present study IES and SPR techniques were employed to systematically investigate the layer-by-layer formation in the kinetic and thermodynamic point of view.

\section{Materials and Methods}

\section{Materials}

Generation 4 of polyamidoamine (PAMAM) dendrimers was purchased from Sigma Aldrich Company. Deoxyribonucleic acid, from calf thymus, peroxidase from horseradish, and 3-mercapto propionic acid (MPA) were purchased from Sigma. Ethanol was obtained from Synth, Brazil. $\mathrm{K}_{3}\left[\mathrm{Fe}(\mathrm{CN})_{6}\right]$ and $\mathrm{K}_{4}\left[\mathrm{Fe}(\mathrm{CN})_{6}\right]$ were acquired from J.T. Baker, USA. All chemicals were of analytical grade and used as received. Phosphate buffer solutions were obtained by mixing solutions of $0.2 \mathrm{~mol} \mathrm{~L}^{-1} \mathrm{Na}_{2} \mathrm{HPO}_{4}$ and $0.2 \mathrm{~mol} \mathrm{~L}^{-1}$ $\mathrm{NaH}_{2} \mathrm{PO}_{4}$ and acetate ones were obtained by mixing $0.2 \mathrm{~mol} \mathrm{~L}^{-1} \mathrm{C}_{2} \mathrm{H}_{4} \mathrm{O}_{2} \mathrm{Na}$ and $0.2 \mathrm{~mol} \mathrm{~L}^{-1} \mathrm{C}_{2} \mathrm{H}_{4} \mathrm{O}_{2}$. All solutions were prepared with deionized water $(>18 \mathrm{M} \Omega \mathrm{cm}$, Milli-Q, Millipore).

\section{Apparatus}

\section{EIS}

All electrochemical experiments were carried out in a conventional three-electrode cell at room temperature using a saturated calomel electrode (SCE) and Pt wire as reference and counter electrodes, respectively. The geometric area of the gold working electrode (Metrohm 6.1204.020, Switzerland) was $0.07 \mathrm{~cm}^{2}$. The impedance measurements were performed using a potentiostat PGSTAT 30 model from AUTOLAB (Eco Chemie, Netherlands) interfaced with a computer.

\section{$S P R$}

The biomolecular interactions were investigated using a SPR system (Autolab Spirit ${ }^{\circledR}$, Eco Chemie, Netherlands). Planar gold SPR disks were purchased from Xantec Bioanalytics (Germany). This equipment is based on the Kretschmann configuration, which is the most commonlyused. The washing solutions were injected in the optical cell using a peristaltic pump at a flow rate of $100 \mu \mathrm{L} \mathrm{min}^{-1}$. The volume of the flow cell was $150 \mu \mathrm{L}$. The flow of washing solution was programmed to stop during the incubation 
steps. The response of the sensor was automatically monitored using a PC with ESPRIT software version 4.1.2.

\section{Modification procedure}

\section{Preparation of the self-assembled monolayer (SAM)}

The cleaning of the bare gold surface is critically important for self-assembled monolayer formation and should be accomplished systematically. The gold disk was immersed in a piranha solution (1:3 mixture of $30 \%$ $\mathrm{H}_{2} \mathrm{O}_{2}$ :concentrated $\mathrm{H}_{2} \mathrm{SO}_{4}$ ) for 5 min. Then, the disk was washed with copious amount of water. After that, the bare gold disk was placed onto the prism of the SPR system and filled with buffer. The resonance angle at this point was recorded as the baseline. A SAM layer of thiols was prepared on the bare gold surface injecting $100 \mu \mathrm{L}$ of $10 \mathrm{mmol} \mathrm{L}^{-1} 3$-mercapto propionic acid solution freshly prepared in ethanol into the cell, and the change of resonance angle was monitored during $120 \mathrm{~min}$ of deposition. The time required for SAM formation was optimized in a previous work. ${ }^{34}$

\section{Layer-by-layer on the sensor}

Alternating layer-by-layer electrostatic adsorption was used to assemble dendrimer, DNA and enzyme films. These films were prepared by assembly method. ${ }^{35}$ After cleaning the gold surface, layers of PAMAM, ds-DNA and enzyme were adsorbed alternately on the gold surface for 15-20 min, rinsing with their respective solvent between adsorption steps Figure 1. Adsorbate solutions were as follows: (a) 2\% PAMAM generation 4; (b) 1-2 $\mathrm{mg} \mathrm{mL}^{-1} \mathrm{DNA}$ and (c) $0.5-5 \mathrm{mg} \mathrm{mL}^{-1}$ horseradish peroxidase in milli-Q water or phosphate ( $\mathrm{pH} 6.8$ ) or acetate buffer $(\mathrm{pH} 4.3)$.

\section{Impedance measurements}

For impedance studies, a sine wave with $10 \mathrm{mV}$ of amplitude was applied to the electrode over the formal potential of the $\mathrm{Fe}(\mathrm{CN})_{6}{ }^{3-14-}$ redox couple $(0.2 \mathrm{~V})$. Impedance spectra were recorded in the frequency range varying from $100 \mathrm{kHz}$ to $100 \mathrm{mHz}$. Electrochemical impedance spectra were fitted using an equivalent circuit contained on the FRA software AUTOLAB (Eco Chemie, Netherlands) and the resistance of charge transfer $\left(\mathrm{R}_{\mathrm{ct}}\right)$ values were determined in a $\mathrm{pH} 4.3$ acetate buffer using $5 \mathrm{mmol} \mathrm{L}^{-1}$ of $\mathrm{Fe}(\mathrm{CN})_{6}^{3-14}$ as redox probe.

\section{Results and Discussion}

\section{Impedance measurements}

Electrochemical impedance spectroscopy is an effective tool to monitor the binding of biomolecules on the electrode surface. The formation of biolayers disturbs the double-charged layer at the electrode/electrolyte interface resulting in the increase of thickness and the insulating character of the electrode surface in relation to the redox probe added to the solution. These changes affect the capacitance and the electron transfer at the electrode interface. At higher frequencies in Nyquist plot, squeeze semicircles represent the electron transfer limited process, followed by a diffusionally limited redox process at lower frequencies. ${ }^{36}$ The diameter of this semicircle, which exhibits the change of the capacitance and interfacial electron transfer resistance $\left(\mathrm{R}_{\mathrm{ct}}\right)$ of the electrodes, can be used as one powerful tool for probing the features of surface-modified electrodes. ${ }^{37}$ Randle's equivalent circuit

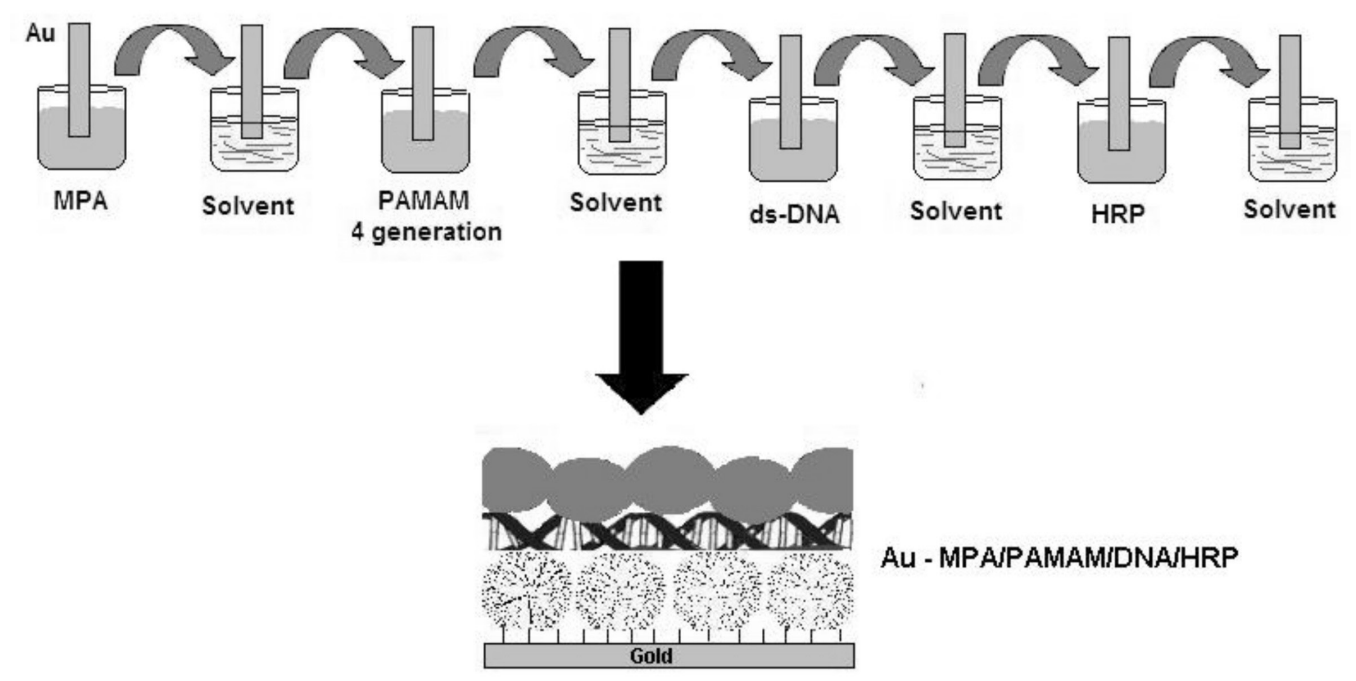

Figure 1. Schematic representation of the process of the film preparation and the materials involved. 
was adopted to model the physiochemical process occurring at the gold electrode surface, which is often used to model the interfacial phenomena: $\mathrm{R}_{\mathrm{s}}\left(\mathrm{CPE}\left[\mathrm{R}_{\mathrm{ct}} \mathrm{W}\right]\right)$ where $\mathrm{R}_{\mathrm{s}}$ is the resistance of the solution, $R_{c t}$ is the resistance of chargetransfer, $\mathrm{W}$ is the Warburg impedance and CPE is a double layer capacitance for constant phase element. ${ }^{38}$

As shown in Figure 2, the gold surface modified with MPA produces a SAM with a large quantity of negative charges from - $\mathrm{COO}^{-}$groups, which is a barrier to electron transfer rates between the electrode and $\left[\mathrm{Fe}(\mathrm{CN})_{6}\right]^{3-14-}$ probe solution. After this step, the adsorption of PAMAM, the positively charged polymer molecule, was performed. The surface becomes positive and would attract the negative charges of $\mathrm{Fe}(\mathrm{CN})_{6}{ }^{3-4-}$ decreasing the $\mathrm{R}_{\mathrm{ct}}$ values, ${ }^{27}$ according to Table 1 . When the surface is sequentially modified with ds-DNA there is an increase in the $\mathrm{R}_{\mathrm{ct}}$ values because they generate an insulating layer on the modified surface, which makes the electron transfer more difficult. This should be attributed to the repulsive electrostatic interaction increasing the resistance of charge transfer due to the anionic charge of the film and probe. ${ }^{39-41}$ After

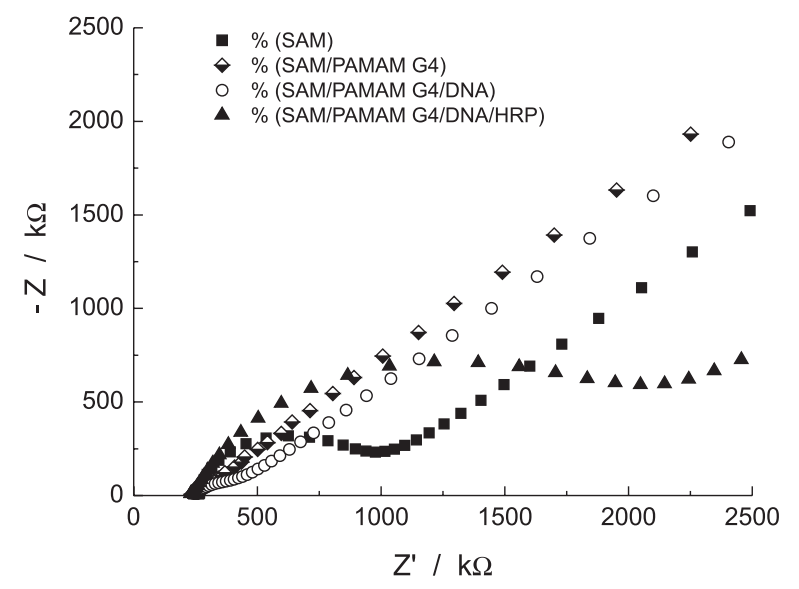

Figure 2. Nyquist plot of layer-by-layer sequential steps onto gold electrodes by adsorption in $5 \mathrm{mmol} \mathrm{L}^{-1} \mathrm{Fe}(\mathrm{CN})_{6}^{3-14-}$ in $\mathrm{pH} 4.3$ acetate buffer solution for the frequency range from $100 \mathrm{kHz}$ to $100 \mathrm{mHz}$ with $10 \mathrm{mV}$ of amplitude: SAM; SAM/PAMAM G4; SAM/PAMAMG4/ds-DNA and SAM/PAMAM G4/ds-DNA/HRP.

Table 1. $\mathrm{R}_{\mathrm{ct}}$ values obtained for different layers formed on gold electrode surface in $5 \mathrm{mmol} \mathrm{L}^{-1} \mathrm{Fe}(\mathrm{CN})_{6}^{3-14}$ in $\mathrm{pH} 4.3$ acetate buffer solution for the frequency range from $100 \mathrm{kHz}$ to $10 \mathrm{mHz}$ with $10 \mathrm{mV}$ of amplitude.

\begin{tabular}{lc}
\hline Layer & $\mathrm{R}_{\mathrm{ct}} / \Omega$ \\
\hline Bare electrode & $19 \pm 3$ \\
SAM & $660 \pm 13$ \\
SAM/PAMAM G4 & $51 \pm 5$ \\
SAM/PAMAM G4/DNA & $149 \pm 8$ \\
SAM/PAMAM G4/DNA/HRP & $1841 \pm 24$ \\
\hline
\end{tabular}

the HRP adsorption, there is a new increase in the $\mathrm{R}_{\mathrm{ct}}$ due to formation of a nonconducting layer. Thus, these data confirm the layers formation.

\section{SPR studies of the layers formation on gold surface}

An important application of SPR technique is the possibility to perform quantitatively the biomolecular interaction by the rate constants and by the equilibrium constants. ${ }^{1,32}$ An SPR interaction plot generally contains three steps: the association, the dissociation and regeneration ones. The association and dissociation steps can be used to determine the rate constants and thereby the equilibrium constants. In an interaction plot, the maximal amount of analyte response is proportional to the ratio of the molecular quantity of analyte and ligand. For SPR system of the Autolab, 1 milli-degree of SPR angle change corresponds to 8.3 resonance unit (RU).

In SPR analysis the low concentrations create detection problems due to its sensitivity. However, most of the compounds of interest have molecular weights of 300 Daltons or more, mainly biological compounds. Thus, this technology is a very attractive method to study biomolecules interactions with specific nucleic acid sequences and immobilized structures to form a biospecific target surface. Figure 3 shows the SPR sensorgrams recorded during each sample injection over a SAM of 3-mercaptopropionic acid. The process of formation of each studied layer was related from the baseline changes before and after sample injection. Thereby, Figure 3 shows a clear stepwise increase in the SPR angle by injection of each component indicating the formation of the layers of PAMAM, ds-DNA and HRP, respectively. Several experimental conditions were investigated varying both the concentrations of the compound and the solvent used. The experiments were carried out at room temperature. Initially, the effect of the solvent was investigated and pure water, phosphate $(\mathrm{pH} 6.8)$ and acetate buffers (4.3) were tested. The best condition obtained by SPR response was in acetate buffer at $\mathrm{pH}$ 4.3. Since the variation of buffer solution and $\mathrm{pH}$ influenced the formation of complex, the interaction among the layers probably occurs mainly by attraction of opposite charges.

The SPR response can be converted to a protein loading according to the relationship: 120 mdegree $=1 \mathrm{ng} \mathrm{mm}^{-2} .42$ According to this relation, an amount of $5.50 \mathrm{ng} \mathrm{mm}^{-2}$ of enzyme was absorbed on the ds-DNA surface when a $5 \mathrm{mg} \mathrm{mL}^{-1}$ solution of enzyme in acetate buffer at $\mathrm{pH} 4.3$ was employed. However, when phosphate buffer was used at $\mathrm{pH} 6.8$ just $0.16 \mathrm{ng} \mathrm{mm}^{-2}$ was adsorbed on the ds-DNA surface. The surface concentration of HRP-ds-DNA film 
formed on modified electrode is about $7.7 \times 10^{-9} \mathrm{~mol} \mathrm{~cm}^{-2}$ and increase linearly with HRP concentration (data not shown). This employed procedure in our studies is about 100 -fold more efficient than those reported by Chen and co-workers ${ }^{43}$ at pyrolytic graphite electrode, since their result to the HRP-DNA film was about $5.1 \times 10^{-11} \mathrm{~mol} \mathrm{~cm}^{-2}$.

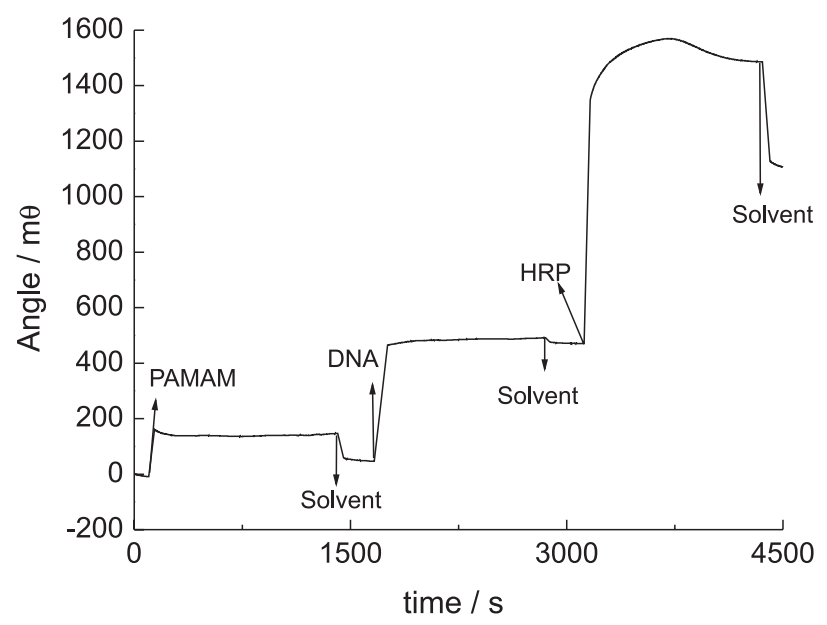

Figure 3. Sensorgram obtained for layer-by-layer immobilization of PAMAM, ds-DNA and HRP on a gold disk modified with a mercaptopropanoic acid SAM using SPR for detection.

Figure 4 shows SPR signal increasing with the concentration of the enzyme, from 0.5 to $5.0 \mathrm{mg} \mathrm{mL}^{-1}$. When the concentration of the HRP in the solution was doubled, the response was almost doubled, suggesting that only specific binding of the HRP to the DNA occurred. ${ }^{44}$ With theses SPR results there is the possibility for assessing the kinetics of interaction between nucleic acid and enzyme used in this investigation. ${ }^{2,3}$ At HRP-ds-DNA layer the association occurred rapidly and reached a steady state at studied conditions.

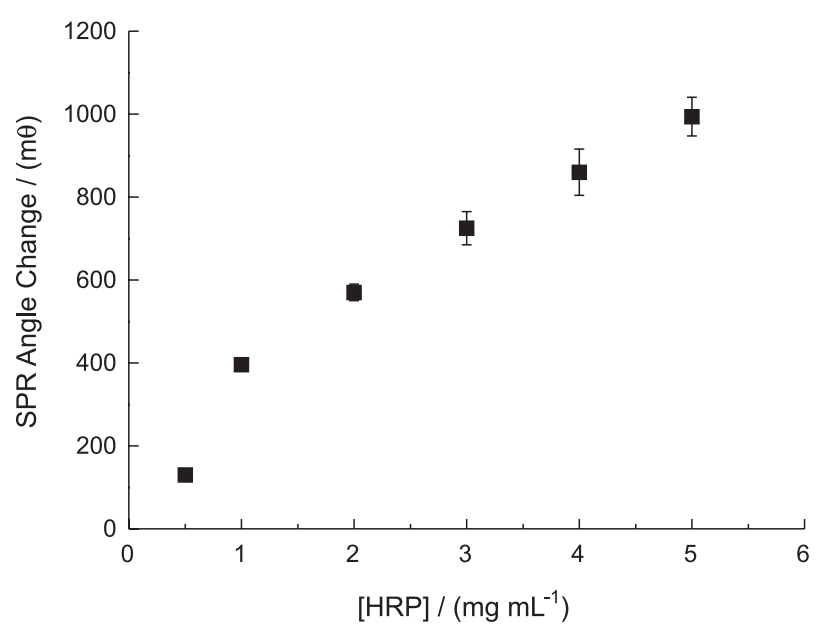

Figure 4. The study of surface plasmon resonance angle changes of the interaction between DNA and HRP at different HRP concentrations; the concentration were from 0.5 to $5.0 \mathrm{mg} \mathrm{mL}^{-1}$ at $\mathrm{pH} 4.3$ acetate buffer.
As noted, the interactions are observed between an immobilized ligand and a soluble ligand. Thus, for the reversible interactions, they can be written as:

ds-DNA + HRP $\underset{\mathrm{kd}}{\stackrel{\mathrm{ka}}{\rightleftharpoons}} \mathrm{ds}-\mathrm{DNA}-\mathrm{HRP}$

The rate of product formation, ds-DNA-HRP, at time $t$ function may be written as:

$\mathrm{d}[\mathrm{ds}-\mathrm{DNA}-\mathrm{HRP}] / \mathrm{dt}=$ $\mathrm{k}_{\mathrm{a}}$ [ds-DNA] [HRP] $-\mathrm{k}_{\mathrm{d}}$ [ds-DNA-HRP]

Where $\mathrm{k}_{\mathrm{a}}$ is the association rate constant and $\mathrm{k}_{\mathrm{d}}$ is the dissociation rate constant. Considering that complex formation of ds-DNA-HRP presents a kinetic of pseudo first $\operatorname{order}^{45-47}$ and after some reaction time, $t,[\mathrm{HRP}]=[\mathrm{HRP}]_{\mathrm{i}}-$ [ds-DNA-HRP]. Substituting into (1) gives:

$\mathrm{d}[\mathrm{ds}-\mathrm{DNA}-\mathrm{HRP}] / \mathrm{dt}=$ $\mathrm{k}_{\mathrm{a}}$ [ds-DNA] ([HRP]i - [ds-DNA-HRP]) - $\mathrm{k}_{\mathrm{d}}$ [ds-DNA-HRP],

Where [HRP]i is the concentration of HRP at $t=0$.

The SPR signal, $\mathrm{R}$, is proportional to the formation of the ds-DNA-HRP complexes at the surface and the maximum signal, $\mathrm{R}_{\max }$, will be proportional to the concentration of active ligand at electrode surface. ${ }^{44}$ Thus, changing d[ds-DNA-HRP] for dR and ds-DNA-HRP complexes for $\mathrm{R}_{\max }$, the equation (2) becomes:

$\mathrm{dR} / \mathrm{dt}=\mathrm{k}_{\mathrm{a}} \mathrm{C}\left(\mathrm{R}_{\max }-\mathrm{R}\right)-\mathrm{k}_{\mathrm{d}} \mathrm{R}$

As already mentioned, $\mathrm{dR} / \mathrm{dt}$ is the rate of formation of surface associated complexes, i.e., the derivative of the observed response curve, $\mathrm{C}$ is the concentration of ligand in solution; $R_{\max }$ is the resonance units, and $\left(R_{\max }-R\right)$ is equivalent to the number of unoccupied surface binding sites at time t. Note that since terms in R appear on both sides of the equation, the response value $\mathrm{R}$ can be used directly without conversion to absolute concentrations of complexes formed at the sensor surface. So, rearranging (3), we have:

$\mathrm{dR} / \mathrm{dt}=\mathrm{k}_{\mathrm{a}} \mathrm{C} \mathrm{R}_{\max }-\left(\mathrm{k}_{\mathrm{a}} \mathrm{C}+\mathrm{k}_{\mathrm{d}}\right) \mathrm{R}$

Equation 4 can be regarded as a straight line $\mathrm{dR} / \mathrm{dt}=$ $-\mathrm{k}_{\text {obs }} \mathrm{R}_{\mathrm{t}}+\mathrm{b}$ with $\mathrm{k}_{\text {obs }}=\mathrm{k}_{\mathrm{a}} \mathrm{C}+\mathrm{k}_{\mathrm{d}}$, and $\mathrm{b}=\mathrm{k}_{\mathrm{a}} \mathrm{CR}_{\text {max }}$. Parameter $\mathrm{k}_{\text {obs }}$ can be determined by linear regression of a plot of $\mathrm{dR} / \mathrm{dt}$ values $v s . \mathrm{R}_{\mathrm{t}}$ values. It is the angular coefficient. Determined $\mathrm{k}_{\text {obs }}$ value is a concentration-dependent parameter. ${ }^{48}$

Figure 5 shows a plot of $\mathrm{dR} / \mathrm{dt}$ versus $\mathrm{R}$ from the HRP interaction with DNA using $[\mathrm{HRP}]=2.5 \times 10^{-5} \mathrm{~mol} \mathrm{~L}^{-1}$. For 


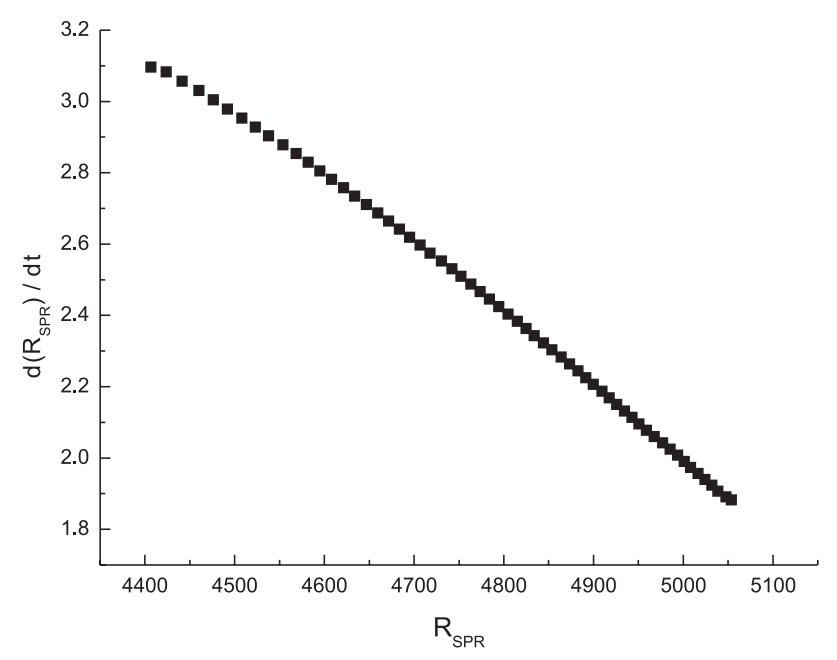

Figure 5. A plot of the association phase of an interaction between ds-DNA and HRP biomolecules by linearization method. $[\mathrm{HRP}]=2.5 \times 10^{-5} \mathrm{~mol} \mathrm{~L}^{-1}$.

each enzyme concentration studied we have obtained a plot of $\mathrm{dR} / \mathrm{dt}$ versus $\mathrm{R}$. For each plot was obtained one $\mathrm{k}_{\mathrm{obs}}$.

Figure 6 shows a plot of $\mathrm{k}_{\text {obs }}$ versus HRP concentration which allows getting a single value for $\mathrm{k}_{\mathrm{a}}$, the slope, and $\mathrm{k}_{\mathrm{d}}$, the $\mathrm{y}$-intercept. The value of $\mathrm{k}_{\mathrm{a}}$ determined is $24.7 \mathrm{~L} \mathrm{~mol}^{-1} \mathrm{~s}^{-1}$ and $\mathrm{k}_{\mathrm{d}}$ is $1.2 \times 10^{-3} \mathrm{~s}^{-1}$. The association constant value obtained in the system shows that complex formation reaction is not so fast when compared to Antp homeodomain (gene that encodes transcription factors which play major roles in determining cell fate) and ss-DNA binding with a $\mathrm{k}_{\mathrm{a}}$ estimated to be almost $10^{5} \mathrm{~L} \mathrm{~mol}^{-1} \mathrm{~s}^{-144}$ or ss-DNA and replication protein A (RPA) with a association rate constant of $10^{6}$ to $10^{7} \mathrm{~L} \mathrm{~mol}^{-1} \mathrm{~s}^{-1}$.,49 The molecular mass of the Antp homeodomain used by Seimiya and Kurosawa ${ }^{44}$ is $8.5 \mathrm{kDa}$, i.e., almost 5-fold lighter than HRP used in these experiments. This feature can raise the association rate of lighter molecules. And also, the values cited for $\mathrm{k}_{\mathrm{a}}$

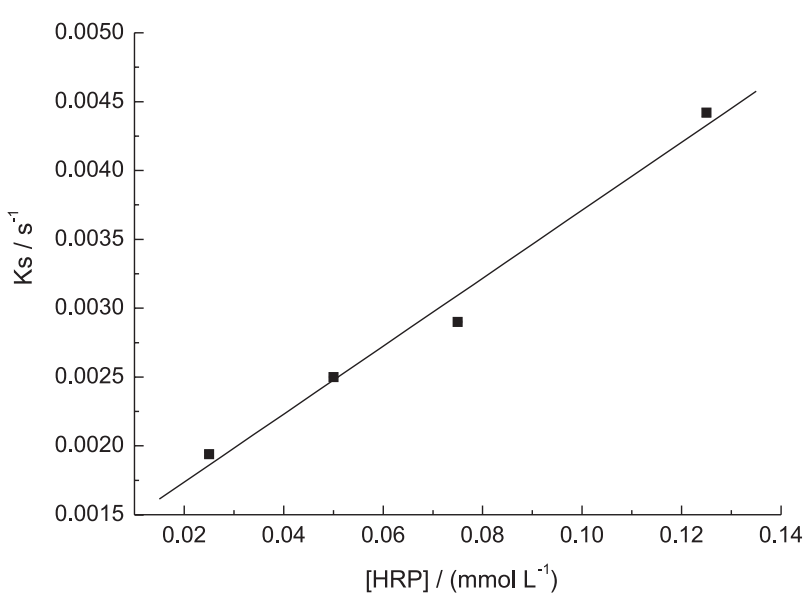

Figure 6. Determination of kinetic parameters from a plot of $\mathrm{K}_{\mathrm{obs}}$ $\left(=\mathrm{k}_{\mathrm{a}} \mathrm{C}+\mathrm{k}_{\mathrm{d}}\right)$ versus $\mathrm{HRP}$ concentration. The slope of the plotted line is equal to the association rate constant, $\mathrm{k}_{\mathrm{a}}$, and the $\mathrm{y}$-intercept is equal to the dissociation rate constant, $\mathrm{k}_{\mathrm{d}}$. of their system should be considered just the average values for mixed reactions, once that occurred specific and nonspecific binding. However, $\mathrm{k}_{\mathrm{d}}$ is comparable to the same system of Antp homeodomain-ss-DNA. ${ }^{44}$

The dissociation constant of our system can be characterized as weak when compared to ss-DNA-RPA binding. ${ }^{3,49}$

Even though the association constant is not so high, it is important to consider that the ration between them, $\mathrm{k}_{\mathrm{a}}$ e $\mathrm{k}_{\mathrm{d}}$, is still favourable. The association rate data may imply certain dependency on the enzyme structure and the availability of the ligand structure.

The equilibrium constant, $\mathrm{K}_{\mathrm{eq}}$, can be calculated from the ratio of rate constants:

$\mathrm{K}_{\mathrm{eq}}=\mathrm{k}_{\mathrm{a}} / \mathrm{k}_{\mathrm{d}}$,

Where $\mathrm{K}_{\mathrm{eq}}$ determined is $20.6 \times 10^{3} \mathrm{~L} \mathrm{~mol}^{-1}$.

Gibbs free energy change $(\Delta \mathrm{G})$ for a reaction is related to the equilibrium dissociation constant, $\mathrm{K}_{\mathrm{eq}}$, by:

$\Delta \mathrm{G}=-\mathrm{R} \mathrm{T} \ln \mathrm{K}_{\mathrm{eq}}$

Thus, a value of $\Delta \mathrm{G}=-5.9 \mathrm{kcal} \mathrm{mol}^{-1}\left(-23.1 \mathrm{~kJ} \mathrm{~mol}^{-1}\right)$ was obtained to HRP and ss-DNA association. This result can not be compared to Protein and ss-DNA binding obtained by Seimiya and Kurosawa ${ }^{44}$ because the value cited for $\Delta \mathrm{G}$ of their system is related to specific and nonspecific bonding and this can increase the stability of the system. It also, the result obtained is lower than the value of Gibbs free energy for ss-DNA and Replication protein A, ${ }^{3}$ but it is known that their system is very stable because the protein A binds efficiently and effectively to ss-DNA used.

The electrocatalytic activity of HRP adsorbed on DNA was tested by the reduction of $\mathrm{H}_{2} \mathrm{O}_{2}$. As HRP contains heme as a prosthetic group, which is also the active site of protein, and it can catalyze the hydrogen peroxidedependent one electron oxidation. Thus, the apparent Michaelis-Menten constant $\left(\mathrm{K}_{\mathrm{M}}\right)$, which indicates the kinetics of enzyme-substrate reaction, was calculated according to the electrochemical version of the LineweaverBurk equation. ${ }^{50,51}$ The reduction peak current increased with the concentration of $\mathrm{H}_{2} \mathrm{O}_{2}$ enhanced and at higher concentration, a response plateau was observed (data not shown)..$^{52}$

$$
1 / \mathrm{I}_{\mathrm{ss}}=1 / \mathrm{I}_{\max }+\mathrm{K}_{\mathrm{M}} / \mathrm{I}_{\max } \mathrm{C}
$$

Where $I_{\mathrm{ss}}$ is the steady-state current after the addition of substrate, $\mathrm{C}$ is the bulk concentration of the substrate, $I_{\max }$ is the maximum current measured at the saturated 
substrate conditions. The $\mathrm{K}_{\mathrm{M}}$ in this work was found to be $2.56 \mathrm{mmol} \mathrm{L}^{-1}$, implying that the system exhibited affinity for $\mathrm{H}_{2} \mathrm{O}_{2}$. This $\mathrm{K}_{\mathrm{M}}$ value is intermediary than some reported values. ${ }^{53-56}$ As is well known, the smaller $\mathrm{K}_{\mathrm{M}}$ shows the higher catalytic ability and it also indicates a larger affinity of the enzyme to the substrate. These results indicated that the peroxidase activity of entrapped HRP was maintained.

In general, this interaction between peroxidase and ds-DNA can also be compared to gold-thiol bond ${ }^{57}$ Thus, these results confirm that interaction between HRP and ds-DNA layer is thermodynamically favourable. Further investigations of stability and applicability of this system will be performed.

\section{Conclusion}

In this study, we have shown by using electrochemical impedance spectroscopy and surface plasmon resonance that peroxidase enzyme adsorbed on the ds-DNA layer on modified gold electrode. Electrochemical impedance spectroscopy allowed the monitoring of the successful construction of the multicomponent film on the gold surface. And also, continuous monitoring of the SPR signal allowed to obtain the kinetic data of the system desired. The reaction showed that the interaction of the peroxidase on ds-DNA layer is favourable once both kinetic constants and binding energy are comparable to DNA-protein interaction. The interaction constants of our system are as strong as a gold-thiol bond. This procedure employed enables us to monitor the interaction of proteins in real time allowing further applications as a biosensor.

\section{Acknowledgments}

The authors thank FAPESP and CNPq for the financial support.

\section{References}

1. Nguyen, B.; Tanious, F. A.; Wilson, W. D.; Methods 2007, 42, 150.

2. O'Shannessy, D. J.; Brigham-Burke, M.; Soneson, K. K.; Hensley, P.; Brooks, I.; Anal. Biochem. 1993, 212, 457.

3. Schubert, F.; Zettl, H.; Hafner, W.; Krauss, G.; Krausch, G.; Biochemistry 2003, 42, 10288.

4. Cahova-Kucharikova, K.; Fojta, M.; Mozga, T.; Palecek, E.; Anal. Chem. 2005, 77, 2920.

5. Liu, J.; Roussel, C.; Lagger, G.; Tacchini, P.; Girault, H. H.; Anal. Chem. 2005, 77, 7687.

6. Palecek, E.; Fojta, M.; Tomschik, M.; Wang, J.; Biosens. Bioelectron. 1998, 13, 621.
7. Zhou, L.; Yang, J.; Estavillo, C.; Stuart, J. D.; Schenkman, J. B.; Rusling, J. F.; J. Am. Chem. Soc. 2003, 125, 1431.

8. Chen, G.-P.; Wang, X.; Liu, A.-R.; Qian, D.-J.; Mater Sci. Eng. C. 2009, 29, 925.

9. Sato, K.; Kodama, D.; Anzai, J.; Anal. Sci. 2005, 21, 1375.

10. Zhao,W.; Xu, J. J.; Chen, H. Electroanalysis 2006, 18, 1737.

11. Caruso, F.; Niikura, K.; Furlong, D. N.; Okahata, Y.; Langmuir 1997, 13, 3427.

12. Cui, X. Q.; Pei, R. J.; Wang, Z. Z.; Yang, F.; Ma, Y.; Dong, S. J.; Yang, X. R.; Biosens. Bioelectron. 2003, 18, 59.

13. Linman, M. J.; Culver, S. P.; Cheng, Q.; Langmuir 2009, 25 , 3075 .

14. Wang, M. J.; Wang, L. Y.; Yuan, H.; Ji, X. H.; Sun, C.Y.; Ma, L.; Bai, Y. B.; Li, T. J.; Li, J. H.; Electroanalysis 2004, $16,757$.

15. Zu, Y.; Liu, H.; Y. Zhang, N. Hu, Electrochim. Acta 2009, 54, 2706.

16. Shimazaki, Y.; Mitsuishi, M.; Ito S.; Yamamoto, M.; Langmuir 1998, 14, 2768.

17. Katsuhiko, A.; Hill, J. P.; Ji, Q.; Phys. Chem. Chem. Phys. 2007, 9, 2319.

18. Liu, Y.; Hu, N.; Biosens. Bioelectron. 2007, 23, 661.

19. Lvov, Y. M.; Lu, Z.; Schenkman, J. B.; Zu, X.; Rusling, J. F.; J. Am. Chem. Soc. 1998, 120, 4073.

20. Rusling, J. F.; Hvastkovs, E. G.; Hull, D. O.; Schenkman, J. B.; Chem. Commun. 2008, 141.

21 So, M.; Hvastkovs, E. G.; Bajrami, B.; Schenkman, J. B.; Rusling. J. F.; Anal. Chem. 2008, 80, 1192.

22. Tarun, M.; Bajrami, B.; Rusling, J. F.; Anal. Chem. 2006, 78, 624.

23. Jang, W.-D.; Selim, K. M. K.; Lee, C.-H.; Kang, I.-K.; Progr. Polymer. Sci. 2009, 34, 1.

24. Zeng, Y.-L.; Huang, H.-W.; Jiang, J. H.; Tian, M.-N.; Li, C.-X.; Tang, C.-R.; Shen, G.-L.; Yu, R.-Q.; Anal. Chim. Acta 2007, 604,170 .

25. Fant, K.; Esbjorner, E. K.; Lincoln, P.; Norden, B.; Biochemistry 2008, 47, 1732.

26. Zhou, L.; Gan, L.; Li, H.; Yang, X.; J. Pharmaceut. Biomed. Anal. 2007, 43, 330.

27. Zhu, N.; Gu, Y.F.; Chang, Z.; He, P. G.; Fang, Y. Z.; Electroanalysis 2006, 18, 2107.

28. Singh, K. V.; Pandey, R. R.; Wang X.; Lake, R.; Ozkan, C. S.; Wang, K.; Ozkan, M.; Carbon 2006, 44, 1730.

29. Yan, H.; Zhang, X. P.; Shen, Z. Y.; Seeman, N. C.; Nature 2002, 415, 62.

30. Kurita, R.; Nakamoto, K.; Ueda, A.; Niwa, O.; Electroanalysis 2008, 20, 2241.

31. Mendes, R. K.; Carvalhal, R. F.; Stach-Machado, D. R.; Kubota, L. T.; Biosens. Bioelectron. 2009, 24, 2483.

32. Wang, J.; Wang, F.; Xu, Z.; Wang, Y.; Dong, S.; Talanta 2007, $74,104$. 
33. Englebienne, P.; Van Hoonacker, A.; Verhas, M.; Spectroscopy 2003, 17, 255.

34. Mendes, R. K.; Carvalhal, R. F.; Kubota, L. T.; J. Electroanal. Chem. 2008, 612, 164.

35. So, M.; Hvastkovs, E. G.; Schenkman, J. B.; Rusling, J. F.; Biosens. Bioelectron. 2007, 23, 492.

36. Billah, M.; Hays, H. C. W.; Millner, P. A.; Microchim. Acta 2008, 160, 447.

37. Darain, F.; Park, D. S.; Park, J. S.; Shim, Y. B.; Biosens. Bioelectron. 2004, 19, 1245.

38. Zhu, N.; Gao, H.; Gu, Y.F.; Xu, Q.; He, P.G.; Fang, Y.Z.; Analyst 2009, 134, 860 .

39. Li, D.; Zou, X.; Shen, Q.; Dong, S.; Electrochem. Commun. 2007, 9, 191.

40. Li, N.; Yuan, R.; Chai, Y.; Chen, S.; Na, H.; Bioprocess. Biosyst. Eng. 2008, 31, 551.

41. Min, K.; Cho, M.; Han, S-Y.; Smi, Y.-B.; Ku, J.; Ban, C.; Biosens. Bioelectron. 2008, 23, 1819.

42. Stenberg, E.; Persson, B.; Roos, H.; Urbaniczky, C.; J. Colloid Interface Sci. 1991, 143, 513.

43. Chen, X.; Ruan, C.; Kong, J.; Deng, J.; Anal. Chim. Acta 2000, 412, 89.

44. Seimiya, M.; Kurosawa, Y.; FEBS Lett. 1996, 398, 279.

45. Fägerstam, L. G.; Frostell-Karlsson, A.; Karlsson, R.; Persson, B.; Rönnberg, I.; Chromatogr. 1992, 227, 176.
46. Karlsson, R.; Miachaelsson, A.; Matsson, L.; J. Immunol. Methods 1991, 145, 229.

47. Malmborg, A.-C.; Michaëlsson, A.; Ohlin, M.; Jansson, B.; Borreback, C. A. K.; Scand. J. Immunol. 1992, 35, 643.

48. Morton, T. A.; Myszka, D. G.; Chaiken, I. M.; Anal. Biochem. 1995, 227, 176.

49. Wang, M.; Mahrenholz, A.; Lee, S.-H.; Biochemistry 2000, 39 , 6433.

50. Sun, W.; Gao, R. F.; Jiao, K.; J. Phys. Chem. B 2007, 111, 4560.

51. Li, J.; Tan, H.; Ge, H. Anal. Chim. Acta 1996, 335, 137.

52. Huang, R.; Hu, N. Bioelectrochemistry 2001, 54, 75.

53. Fan, D.-H.; Sun, J.-Y.; Huang, K.-J.; Colloid Surf. B: Biointerfaces 2010, 76, 44.

54. Hui, N.; Gao, R.-F.; Li, X.-Q.; Sun, W.; Jiao, J.; J. Braz. Chem. Soc. 2009, 20, 252.

55. Li, J.; Tan, S. N.; Ge, H. L.; Anal. Chim. Acta 1996, 335, 137.

56. Fan, C. H; Wang, H. Y; Zhu, D.; Wagner, G.; Li, G. X; Anal. Sci. 2001, 17, 273.

57. Damos, F. S.; Luz, R. C. S.; Kubota, L. T.; Langmuir 2005, 21 , 602.

Submitted: December 12, 2009

Published online: May 20, 2010

FAPESP has sponsored the publication of this article. 